\title{
STUDY OF COMPLICATIONS AND FUNCTIONAL OUTCOME OF FIXATION OF DISTAL TIBIAL FRACTURES WITH ANATOMICAL LOCKING PLATE USING MIPO TECHNIQUE
}

\author{
G. Ramesh ${ }^{1}$, N. Ravinder Kumar ${ }^{2}$
}

${ }^{1}$ Associate Professor, Department of Orthopaedics, Gandhi Medical College, Hyderabad.

${ }^{2}$ Associate Professor, Department of Orthopaedics, Gandhi Medical College, Hyderabad.

\section{ABSTRACT}

\section{BACKGROUND}

Managing the distal tibia fractures is still a challenge to orthopaedic surgeons even today in terms of soft tissue healing, accurate fracture reduction and fixation. ${ }^{1}$ Minimal invasive plate osteosynthesis (MIPO) with anatomical contoured plate is an established technique for fixation of fracture of the distal tibia. ${ }^{2,3}$ Locking plate have the biochemical properties of internal and external fixation with superior holding power. ${ }^{4}$ Because of fixed angular stability through the head of locking screws, independent of fixation fit and if treated by minimal invasive osteosynthesis has the advantage of biological fixation.5,6

The aim is to evaluate the results of minimally invasive plate osteosynthesis using anatomical contoured locking plate in management of distal tibial fractures in terms of radiological fracture union, restoration of ankle function and complications.

\section{MATERIALS AND METHODS}

This is a prospective study of 24 patients with distal tibial fractures treated with minimally invasive antero-medial locking plate. This study evaluates the bone and soft tissue healing along with complications related to soft tissue and bone from Sept. 2013 to Sept. 2014 in Gandhi General Hospital/Gandhi Medical College; 24 patients of distal tibial fractures were operated by MIPO technique with distal tibial anatomical locking plate on anteromedial aspect of tibia and all cases are followed up both pre- and post-operative for a period of 12 months.

\section{RESULTS}

The mean fracture healing time was 20 weeks (Range 14 - 24 weeks). At last followup superficial skin infection with skin dehiscence occurred in 4 patients (16.5\%), delayed union in 2 patients (8.5\%) and ankle stiffness in 2 patients (8.5\%).

\section{CONCLUSION}

The minimally invasive fixation of distal tibial fractures with anteromedial locking plate is a safe_method of fracture stabilisation. This technique should be used in all distal tibial fractures, particularly where interlocking nail cannot be done in distal tibial fracture with small distal metaphyseal fragments, vertical splits and fracture with intra-articular extension.

\section{KEYWORDS}

Distal Tibial Fractures, Anatomical Locking Plate, MIPO Technique.

HOW TO CITE THIS ARTICLE: Ramesh G, Kumar NR. Study of complications and functional outcome of fixation of distal tibial fractures with anatomical locking plate using MIPO technique. J. Evolution Med. Dent. Sci. 2017;6(31):2489-2492, DOI: $10.14260 /$ jemds/2017/539

\section{BACKGROUND}

Fractures of distal tibia are critical because the tibial bone in lower end is subcutaneous with minimal muscle cover and with precarious blood supply, which makes fracture in this part of tibia prone for many complications like wound dehiscence, infections, delayed union, malunion and ankle stiffness following surgery or conservative management.1,7 The ideal treatment for unstable distal tibial fractures remains controversial. Conservative management with pop cast application and immobilisation leads to ankle stiffness (Upto $30 \%$ of cases) as well as shortening and angulation at fracture site in significant number of cases. ${ }^{8}$ Open Reduction and Internal Fixation (ORIF) with conventional plate is associated with high risk of infection, delayed union and non-union because ORIF needs extensive soft tissue dissection. ${ }^{2}$

Financial or Other, Competing Interest: None.

Submission 16-08-2016, Peer Review 27-08-2016,

Acceptance 30-08-2016, Published 14-04-2017.

Corresponding Author:

Dr. G. Ramesh,

\#2/3RT. Opp. Post Office,

Vijayanagar Colony, Hyderbad-500057.

E-mail: drrameshgaripalli@yahoo.co.in

DOI: $10.14260 /$ jemds $/ 2017 / 539$
Nail osteosynthesis is the preferred treatment in middle $3^{\text {rd }}$ region shaft fractures, but is not always possible for distal third fractures with small metaphyseal fragment, spiral fractures and comminuted fractures. ${ }^{9}$

Minimally Invasive Plate Osteosynthesis (MIPO) using anatomically contoured locking plate reduces iatrogenic soft tissue injury and preserves bone vascularity, ${ }^{2}$ and aims to achieve correct limb length and both axial and rotational alignment of the bone fragments 5,4,6 with minimal damage at bone fracture site, while preserving fracture haematoma. 10 Results of closed reduction and percutaneous plating for distal tibial fractures are encouraging. We studied prospectively 24 number of cases who underwent MIPO for distal tibial fractures and evaluated them for functional and radiological outcome in these cases.

\section{MATERIALS AND METHODS}

We prospectively analysed patients with distal tibial fractures came to Gandhi Medical Hospital/Gandhi Medical College between Sept. 2013 to Sept. 2014. During this period, a total number of 24 patients were operated as aged between 25 - 80 years with mean age of 39 years. There were 20 males and 4 female patients. All fractures are classified according to RuediAllgower classification ${ }^{8}$ and Gustilo-Anderson classification. All closed fractures and Gustilo-Anderson type I and type II 
compound fractures of distal tibia with or without intraarticular extension upto 10 days old fracture are included in the study. Pathological fractures, compound fractures, GustiloAnderson type III and fractures more than 2 weeks old are excluded from this study. In all the patients at the time of admission, a careful history was taken to identify the mechanism of injury, severity of trauma. All the patients were submitted to routine AP and lateral view $x$-ray of leg and ankle were taken. All the patients were evaluated to these general conditions and below knee pop slab were applied till the surgery was taken up. Surgical profile, consent for surgery and appropriate prophylactic antibiotics were given before surgery.

\begin{tabular}{|c|c|c|c|}
\hline \multicolumn{2}{|c|}{ Parameter } & Degree & Score \\
\hline \multirow{4}{*}{1.} & \multirow{4}{*}{ Pain } & None & 25 \\
\hline & & $\begin{array}{l}\text { While Walking on } \\
\text { Uneven Surface }\end{array}$ & 20 \\
\hline & & $\begin{array}{c}\text { While Walking on Even } \\
\text { Surface Outdoors }\end{array}$ & 10 \\
\hline & & $\begin{array}{c}\text { While Walking Indoors } \\
\text { Constant and Severe }\end{array}$ & 5 \\
\hline \multirow{2}{*}{2.} & \multirow{2}{*}{ Stiffness } & None & 10 \\
\hline & & Stiffness & 0 \\
\hline \multirow{3}{*}{3.} & \multirow{3}{*}{ Swelling } & None & 10 \\
\hline & & Only in Evenings & 5 \\
\hline & & Constant & 0 \\
\hline \multirow{3}{*}{4.} & \multirow{3}{*}{$\begin{array}{l}\text { Stair- } \\
\text { Climbing }\end{array}$} & No Problems & 10 \\
\hline & & Impaired & 5 \\
\hline & & Impossible & 0 \\
\hline \multirow{2}{*}{5.} & \multirow{2}{*}{ Running } & Possible & 5 \\
\hline & & Impossible & 0 \\
\hline \multirow{2}{*}{6.} & \multirow{2}{*}{ Jumping } & Possible & 5 \\
\hline & & Impossible & 0 \\
\hline \multirow{2}{*}{7.} & \multirow{2}{*}{ Squatting } & No problems & 5 \\
\hline & & Impossible & 0 \\
\hline \multirow{3}{*}{8.} & \multirow{3}{*}{ Supports } & None & 10 \\
\hline & & Taping, Wrapping & 5 \\
\hline & & Stick or Crutch & 0 \\
\hline \multirow{4}{*}{9.} & \multirow{4}{*}{$\begin{array}{c}\text { Work, } \\
\text { Activities } \\
\text { of } \\
\text { Daily Life }\end{array}$} & Same as Before Injury & 20 \\
\hline & & Loss of Tempo & 15 \\
\hline & & Change to Simpler Job & 15 \\
\hline & & $\begin{array}{l}\text { Severely Impaired } \\
\text { Work Capacity }\end{array}$ & 0 \\
\hline & wa & $\begin{array}{l}\text { d Mollander Scoring } \\
\text { this Study to Assess }\end{array}$ & \\
\hline
\end{tabular}

\begin{tabular}{|c|c|c|}
\hline Age (In years) & No. of Patients & Percentage \\
\hline $21-30$ & 4 & 17 \\
\hline $31-40$ & 8 & 33 \\
\hline $41-50$ & 4 & 17 \\
\hline $51-60$ & 4 & 17 \\
\hline $61-70$ & 2 & 8 \\
\hline $71-80$ & 2 & 8 \\
\hline Total & $\mathbf{2 4}$ & $\mathbf{1 0 0}$ \\
\hline \multicolumn{3}{|c|}{ Sex } \\
\hline Male & 20 & 83 \\
\hline Female & 4 & 17 \\
\hline Total & $\mathbf{2 4}$ \\
\hline \multicolumn{2}{|c|}{ Table 2. Showing Age Distribution } \\
\hline
\end{tabular}

\begin{tabular}{|c|c|c|}
\hline & No. of Patients & Percentage \\
\hline Side of Injury & 16 & 67 \\
\hline Right & 8 & 33 \\
\hline Left & 20 & 83 \\
\hline \multicolumn{3}{|c|}{ Mode of Injury } \\
\hline RTA (High energy) & 4 & 17 \\
\hline Fall (Low energy ) & 18 & 75 \\
\hline \multicolumn{3}{|c|}{ Type } \\
\hline Closed & 6 & 25 \\
\hline Open & Table 3. Side and Mode of Injury \\
\hline
\end{tabular}

\begin{tabular}{|c|c|c|}
\hline & No. of Patients & Percentage \\
\hline Type of Open Fracture & & \\
\hline Type I & 4 & 75 \\
\hline Type II & 2 & 25 \\
\hline Type III A & - & - \\
\hline Type III B & - & - \\
\hline Type III C & - & - \\
\hline Fracture Pattern & & \\
\hline A1 & 6 & 25 \\
\hline A2 & 2 & 8 \\
\hline A3 & 12 & 51 \\
\hline B1 & - & 0 \\
\hline B2 & - & 0 \\
\hline B3 & 2 & 0 \\
\hline C1 & 2 & 8 \\
\hline C2 & - & 0 \\
\hline C3 & - & \\
\hline \multicolumn{2}{|c|}{ Table 4. Showing Duration of } \\
\hline \multicolumn{2}{|c|}{ Surgery and Fracture Union } \\
\hline
\end{tabular}

\section{Surgical Techniques}

Patients were operated under regional anaesthesia under tourniquet control. Patients were placed on C-arm compatible table in supine position, a vertical incision about $3 \mathrm{cms}$ was placed over medial malleolus. The anatomical pre-shaped 4.5 $\mathrm{mm}$ locking plate (Sharma surgical) was inserted extra periosteally under C-arm control. Closed reduction of fracture was obtained by manual traction/calcaneal pin/Schanz pin in distal tibia. Then the plate was implanted with at least 3 locking screws in proximal tibia and distal fragment $(5.0 \mathrm{~mm}$ and $4.5 \mathrm{~mm}$ screws respectively) when there was comminution of fracture; fibula was also fixed with $3.5 \mathrm{~mm}$ reconstruction plate or semi-tubular plate depends on the need for accurate limb length and to maintain stability at fracture site in tibia.

Post-operatively, an above knee pop slab was applied for one week to get the limb oedema to be reduced. Sutures were removed at the end of 2 weeks; early active and passive knee and ankle movements were encouraged on next day of surgery. Touch down weight bearing with help of walker and partial weight bearing started the movement with callus seen on x-ray. Patients were regularly followed up at 3 weeks, 6 weeks and months 3, 6, 9 and 12. Bone union was defined as presence of callus bridging on radiograph and the ability to full weight bearing without pain. 


\begin{tabular}{|c|c|c|}
\hline & No. of Cases & Percentage \\
\hline \multicolumn{3}{|c|}{ Duration of Surgery (In minutes) } \\
\hline $51-60$ & 16 & 68 \\
\hline $61-70$ & 2 & 8 \\
\hline $71-80$ & 2 & 8 \\
\hline $81-90$ & 4 & 16 \\
\hline \multicolumn{3}{|c|}{ Duration of Fracture Union (In weeks) } \\
\hline 14 & 12 & 48 \\
\hline 16 & 8 & 36 \\
\hline 18 & 2 & 8 \\
\hline 20 & 2 & 8 \\
\hline \multicolumn{2}{|c|}{ Table 5. Duration of Surgery and Fracture Union } \\
\hline
\end{tabular}

4 patients (16.6\%) who responded well to regular dressing and extended dose of oral antibiotics for few more days. All the patients sustained direct injury to leg leading to associated soft tissue damage at site of fracture.

Two patients were treated for delayed union as a result of high comminution at the site of fracture in one case and grade 2 compound fracture in other case; both these cases united at the end of 24 weeks. Two patients (8.5\%) developed ankle stiffness with ROM of $50 \%$ of contralateral side due to lack of regular followup, who were advised active movements at guidance of physiotherapist. No patient in our series had plate bending, vascular injury or tourniquet palsy.

\section{RESULTS}

The age of the patients ranged from 25 - 80 years with mean age of 39 years; there were 20 male and 4 female patients. The mode of injury in majority of patients was road traffic accidents. The majority of the fractures included in our series were extra-articular and associated with fibula fracture at about the same level.

The mean duration between trauma and surgery was 7 days with a range of 5 - 12 days. The average surgery time was 90 minutes with average time of $70-140$ minutes. The mean fracture healing time was 20 weeks (14 - 24 weeks), mean hospital stay was 16 days ( 8 - 20 days). Partial weight bearing with crutches started at 10 days and the mean time of callus formation was 10 weeks. The mean time for full weight bearing was 15 weeks (Between 8 - 22 weeks). On average $60 \%$ of patients had Oleaur and Mollander et al score of 80 points out of 100 points with average of 90 points. We encountered superficial skin infection and dehiscence in about

\begin{tabular}{|c|c|}
\hline Score & Results \\
\hline $100-80$ & Excellent \\
\hline $50-79$ & Good \\
\hline $25-49$ & Fair \\
\hline$<25$ & Poor \\
\hline $\begin{array}{c}\text { Table 6. Rating According to Oleaur } \\
\text { and Mollander Scoring System }\end{array}$ \\
\hline
\end{tabular}

\begin{tabular}{|c|c|c|}
\hline Complications & No. of Patients & Percentage \\
\hline Superficial Skin Infection & 2 & 16 \\
\hline Ankle Movement Restriction & & \\
\hline$>75 \%$ & 0 & 0 \\
$50-75 \%$ & 0 & 0 \\
$25-50 \%$ & 0 & 0 \\
$<25 \%$ & 2 & 16 \\
\hline Anterior angulation $5^{\circ}$ & 0 & 0 \\
\hline \multicolumn{2}{|c|}{ Table 7. Showing Complications } \\
\hline
\end{tabular}

\begin{tabular}{|c|c|c|c|c|c|c|}
\hline Rating & $\begin{array}{c}\text { Ankle/Subtalar } \\
\text { Motion }\end{array}$ & $\begin{array}{c}\text { Tibiotalar } \\
\text { Alignment }\end{array}$ & $\begin{array}{c}\text { Tibial } \\
\text { Shortening }\end{array}$ & $\begin{array}{c}\text { Chronic } \\
\text { Swelling }\end{array}$ & $\begin{array}{c}\text { Pronation/ } \\
\text { Supination }\end{array}$ & $\begin{array}{c}\text { Equinus } \\
\text { Deformity }\end{array}$ \\
\hline Excellent & $>75 \%$ Normal & Normal & None & None & Normal & None \\
\hline Good & $50-75 \%$ & Normal & None & Minimal & Normal & None \\
\hline Fair & $25-50 \%$ & $<5$ U Angulation & $<1 \mathrm{~cm}$ & Moderate & $\begin{array}{c}\text { Moderate } \\
\text { Decrease }\end{array}$ & None \\
\hline Poor & $<25 \%$ & $>1 \mathrm{~cm}$ & Severe & Marked Decrease & Present \\
\hline \multicolumn{7}{|c|}{ Table 8. Showing Objective Criteria (American Ankle \& Foot Score) } \\
\hline
\end{tabular}

\section{DISCUSSION}

The distal tibial fractures remain a challenge to orthopaedic surgeons even today, because of dilemma of method of fracture fixation either open plate/locked ILN or conservative management with pop casing. ${ }^{1,7}$ Minimally invasive percutaneous osteosynthesis with anatomical pre-contoured distal tibial plate was now an established technique of management of distal tibial fractures.11,12 Conservative management with pop immobilisation was associated with prolonged period of rest and ankle stiffness. Open reduction and DCP plate fixation and locked IM nails were associated with more number of infections, delayed union, non-union of fracture and soft tissue healing problems from dissection of soft tissue while doing surgery. ${ }^{10,9}$ Damage to distal tibial extraosseous blood supply provided by branches at anterior and posterior tibial arteries was least with MIPO technique. Hence, chances of complications are less and rate of bone union was high. ${ }^{12}$ We evaluated our results and compared with those obtained by various other studies utilising different modalities of treatment and MIPO technique for distal tibial fractures as our analysis follows. Our study revealed the average age of patients was 39 years (25 - 80 years), was comparable with study on similar fractures conducted by other authors. In our study more number of male patients are involved over females, i.e. 85\% compared to the study conducted by Collinge $\mathrm{C}$ et $\mathrm{al},{ }^{11}$ which was $77 \%$ possible due to the fact that males travel a lot and these are occupational injuries. Our study had $25 \%$ compound fractures, was compatible to studies conducted by Heather and Vallier ${ }^{9}$ et al who had $30 \%$ open fractures. The average operation time was 60 minutes ( 55 - 85 minutes) comparable with the average of 77 minutes by J. J. Guo et al in their study. The average time taken for fracture to unite was 24 weeks comparable to 16 - 28 weeks in various studies ${ }^{11,12}$ conducted using MIPO technique, which was comparable to our study.

\section{CONCLUSION}

The MIPO technique for fracture of distal tibial fracture was an established procedure with less incidence of delayed union, non-union, skin complications and infections because of less 


\section{Jemds.com}

disturbance to bone vascularity and soft tissue damage around fracture site during surgery. MIPO technique can be used even in distal tibial fractures with small distal fragment, comminuted fractures and fracture with intra-articular extension.

\section{REFERENCES}

[1] Sirkin M, Sanders R. The treatment of pilon fractures. Orthop Clinic North Am 2001;32(1):91-102.

[2] Collinge CA, Sanders RW. Percutaneous plating in the lower extremity. J Amer Acad Orthop Surg 2000;8(4): 211-6.

[3] Collinge C, Sanders R, DiPasquale T. Treatment of complex tibial periarticular fractures using percutaneous techniques. Clin Orthop Relat Res 2000;375:69-77.

[4] Egol KA, Kubiak EN, Fulkerson E, et al. Biomechanics of locked plates and screws. J Orthop Trauma 2004;18(8): 488-93.

[5] Helfet DL, Shonnard PY, Levine D, et al. Minimally invasive plate osteosynthesis of distal fractures of the tibia. Injury 1997;28(Suppl 1):A42-8.

\section{Original Research Article}

[6] Kaab MJ, Frenk A, Schmeling A, et al. Locked internal fixator: sensitivity of screw/plate stability to the correct insertion angle of the screw. J Orthop Trauma 2004;18(8): 483-7.

[7] Mast JW, Spiegel PG, Pappas JN. Fractures of tibial pilon. Clin Orthop Relat Res 1988;230:68-82.

[8] Ruedi TP, Allgower M. The operative treatment of intra- articular fractures of the lower end of tibia. Clin Orthop Relat Res 1979;138:105-10.

[9] Vallier HA, Le TT, Bedi A. Radiographic and clinical comparisons of distal tibia shaft fractures $(4-11 \mathrm{cms}$ proximal to plafond) plating versus intramedullary nailing. J Orthop Trauma 2008;22(5):307-11.

[10] Ronga M, Shanmugam C, Longo UG, et al. Minimally invasive osteosynthesis of distal tibial fractures using locking plates. Ortho Clin North Am 2009;40(4):499504.

[11] Collinge C, Protzman R. Outcomes of minimally invasive plate osteosynthesis for metaphyseal distal tibia fractures. J Orthop Trauma 2010;24(1):24-9.

[12] Hazarika S, Chakravarthy J, Cooper J. Minimally invasive locking plate osteosynthesis for fractures of the distal tibia-results in 20 patients. Injury 2006;37(9):877-87. 